\title{
A Method for Determining Average Beach Slope and Beach Slope Variability for U.S. Sandy Coastlines
}

By Kara S. Doran, Joseph W. Long, and Jacquelyn R. Overbeck

Open-File Report 2015-1053

U.S. Department of the Interior

U.S. Geological Survey 


\section{U.S. Department of the Interior \\ SALLY JEWELL, Secretary}

\section{U.S. Geological Survey \\ Suzette M. Kimball, Acting Director}

U.S. Geological Survey, Reston, Virginia: 2015

For more information on the USGS-the Federal source for science about the Earth, its natural and living resources, natural hazards, and the environment-visit http://www.usgs.gov or call 1-888-ASK-USGS

For an overview of USGS information products, including maps, imagery, and publications, visit http://www.usgs.gov/pubprod

To order this and other USGS information products, visit http://store.usgs.gov

Suggested citation:

Doran, K.S., Long, J.W., and Overbeck, J.R., 2015, A method for determining average beach slope and beach slope variability for U.S. sandy coastlines: U.S. Geological Survey Open-File Report 2015-1053, 5 p., http://dx.doi.org/10.3133/ofr20151053.

Any use of trade, product, or firm names is for descriptive purposes only and does not imply endorsement by the U.S. Government.

Although this report is in the public domain, permission must be secured from the individual copyright owners to reproduce any copyrighted material contained within this report.

ISSN 2331-1258 (online) 


\section{Contents}

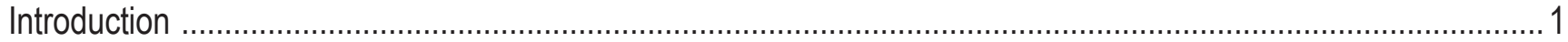

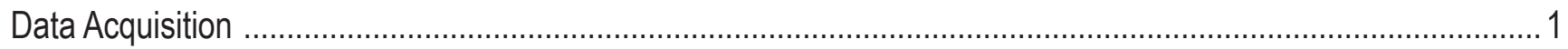

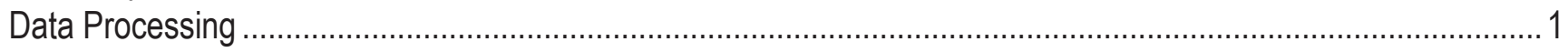

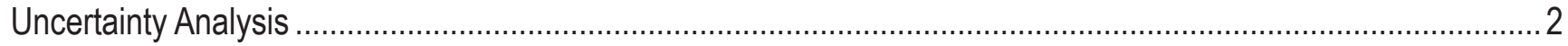

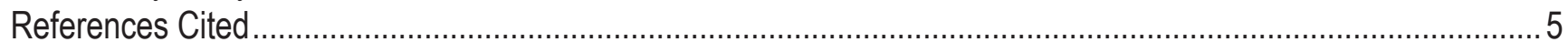

\section{Figures}

1. Cross-shore profile of lidar-based elevations from the Outer Banks of North Carolina, surveyed in November 2012, indicating the locations and elevations of the dune crest, dune toe, shoreline, mean beach slope,

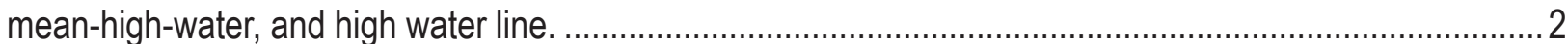

2. An example of spatially and temporally averaged beach slopes computed using data collected between 1996 and 2012 for the Outer Banks of North Carolina.

3. Spatially and temporally averaged beach slopes for a 1-kilometer section of coast in the Outer Banks of North Carolina 


\section{Conversion Factors}

\section{SI to Inch/Pound}

\begin{tabular}{lcc}
\hline \multicolumn{1}{c}{ Multiply } & By & To obtain \\
\hline centimeter (cm) & Length & \\
meter (m) & 0.3937 & inch (in.) \\
meter (m) & 3.281 & foot (ft) \\
kilometer (km) & 1.094 & yard (yd) \\
\hline
\end{tabular}

\section{Datum}

Vertical coordinate information is referenced to the North American Vertical Datum of 1988 (NAVD 88).

Horizontal coordinate information is referenced to the North American Datum of 1983 (NAD 83).

Elevation, as used in this report, refers to distance above the vertical datum.

\section{Abbreviations}

$\begin{array}{ll}\text { HWL } & \text { High water line } \\ \text { MHW } & \text { Mean high water } \\ \text { MRE } & \text { Mean residual error } \\ \text { NOAA } & \text { National Oceanic and Atmospheric Administration } \\ \text { RMS } & \text { Root mean square } \\ \text { USACE } & \text { U.S. Army Corps of Engineers } \\ \text { USGS } & \text { U.S. Geological Survey }\end{array}$




\title{
A Method for Determining Average Beach Slope and Beach Slope Variability for U.S. Sandy Coastlines
}

\author{
By Kara S. Doran, Joseph W. Long, and Jacquelyn R. Overbeck
}

\section{Introduction}

The U.S. Geological Survey (USGS) National Assessment of Hurricane-Induced Coastal Erosion Hazards compares measurements of beach morphology with storm-induced total water levels to produce forecasts of coastal change for storms impacting the Gulf of Mexico and Atlantic coastlines of the United States. The wave-induced water level component (wave setup and swash) is estimated by using modeled offshore wave height and period and measured beach slope (from dune toe to shoreline) through the empirical parameterization of Stockdon and others (2006). Spatial and temporal variability in beach slope leads to corresponding variability in predicted wave setup and swash. For instance, seasonal and storm-induced changes in beach slope can lead to differences on the order of 1 meter $(\mathrm{m})$ in wave-induced water level elevation, making accurate specification of this parameter and its associated uncertainty essential to skillful forecasts of coastal change. A method for calculating spatially and temporally averaged beach slopes is presented here along with a method for determining total uncertainty for each 200-m alongshore section of coastline.

\section{Data Acquisition}

The combination of laser-based ranging with inertial and GPS-based navigation provides an efficient method for collecting high-resolution data of sub-aerial topography with sufficient accuracy (root-mean-square $[R M S]$ vertical accuracy $=15$ centimeters $[\mathrm{cm}]$; horizontal accuracy $=1-1.5 \mathrm{~m}$ ) to resolve the spatial details of coastal morphology (Sallenger and others, 2003). Processed lidar datasets have been acquired from various sources including the USGS, U.S. Army Corps of Engineers (USACE), and the National Oceanic and Atmospheric Administration (NOAA) Digital Coast Web site. Lidar datasets are often available in two different return types: first return and bare earth. First return data include vegetation and are noisier, while bare earth data reflect the ground elevation underneath vegetation. The focus of this method is the extraction of beach slope along the section of beach between the dune toe and shoreline, which has little to no vegetation and will not be affected significantly when either first return or bare earth data are used. When available, bare earth data are preferred over first return data because of the extra quality control and editing that occurs with bare earth data processing.

Ground-based measurements of beach profiles may also be used to estimate beach slope, provided the profile covers the area of the beach between the dune toe and the shoreline. The same data processing techniques that are used to derive beach morphology from lidar data can be applied to groundbased beach profiles.

\section{Data Processing}

Three-dimensional lidar data from each individual survey are gridded using a fixed-scale interpolator (Plant and others, 2002), which allows for variability in cross-shore and alongshore resolution, here, $2.5 \mathrm{~m}$ and $10 \mathrm{~m}$, respectively. In addition to a gridded topographic surface, this method produces a 
corresponding grid of the residual error, which provides a measure of noise in the data. A Hanning filter with a width equal to two times the grid resolution was chosen to minimize noise in the data associated with vegetation, alongshore variability, and other error sources while preserving distinct morphologic characteristics. Analysis of cross-shore profiles of gridded data allows for automated extraction of morphologic features including the dune crest $\left(x_{c}, z_{c}\right)$, dune toe $\left(x_{t}, z_{t}\right)$, shoreline position $\left(x_{s l}, z_{s l}\right)$, and mean beach slope $\left(\beta_{m}\right)$ at 10-m alongshore intervals (fig. 1). Here, the shoreline is referenced to a mean-highwater (MHW) level position. Detailed descriptions of the algorithm used to extract shoreline position, dune crest, and dune toe can be found in Stockdon and others (2012). The mean beach slope is calculated using an endpoint method with the dune toe and the MHW shoreline as the landward and seaward limits, respectively. If a dune is not present, then the berm crest $\left(x_{c}, z_{c}\right)$ becomes the landward limit. The averaged beach slope is computed every $200 \mathrm{~m}$ by applying a 400-m wide Hanning window and averaging over all survey times (fig. 2).

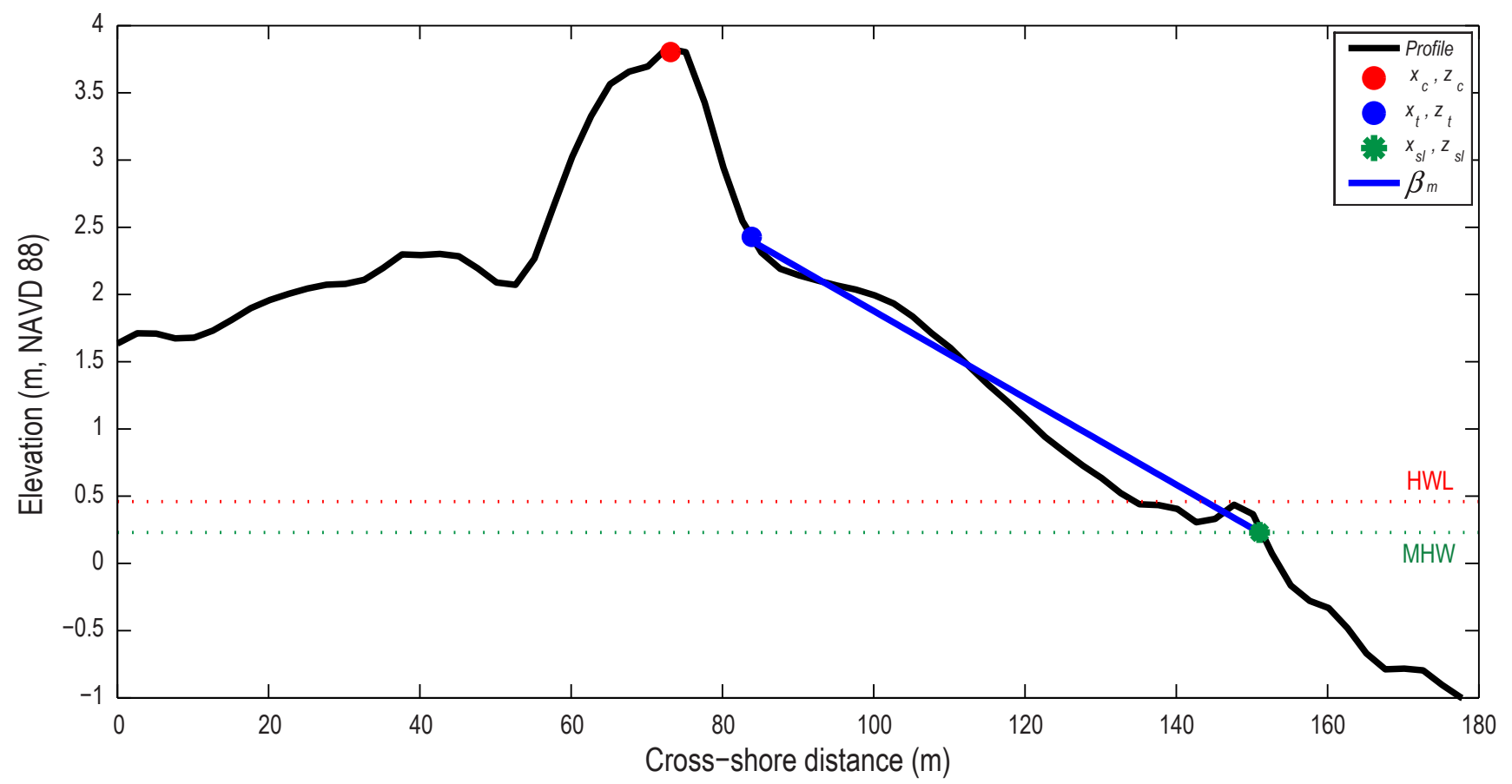

Figure 1. Cross-shore profile of lidar-based elevations from the Outer Banks of North Carolina, surveyed in November 2012, indicating the locations and elevations of the dune crest $\left(x_{c}, z_{c}\right)$, dune toe $\left(x_{t}, z_{t}\right)$, shoreline $\left(x_{s l}, z_{s l}\right)$, mean beach slope $\left(\beta_{m}\right)$, mean-high-water (MHW), and high water line (HWL). [m, meter; NAVD 88, North American Vertical Datum of 1988].

\section{Uncertainty Analysis}

Beach slope can vary with tidal cycles (hours to days), seasonal cycles (months), following storm events, or human-induced alterations to the coast, such as beach nourishment or scraping. Slopes also vary alongshore as the beach becomes narrower or wider. Because wave setup and swash elevations are sensitive to beach slope, estimating total uncertainty in the mean beach slope using all available survey information is necessary to compute the corresponding uncertainty in total water level predictions in advance of storm events. The total uncertainty in beach slope is defined as the mean residual 


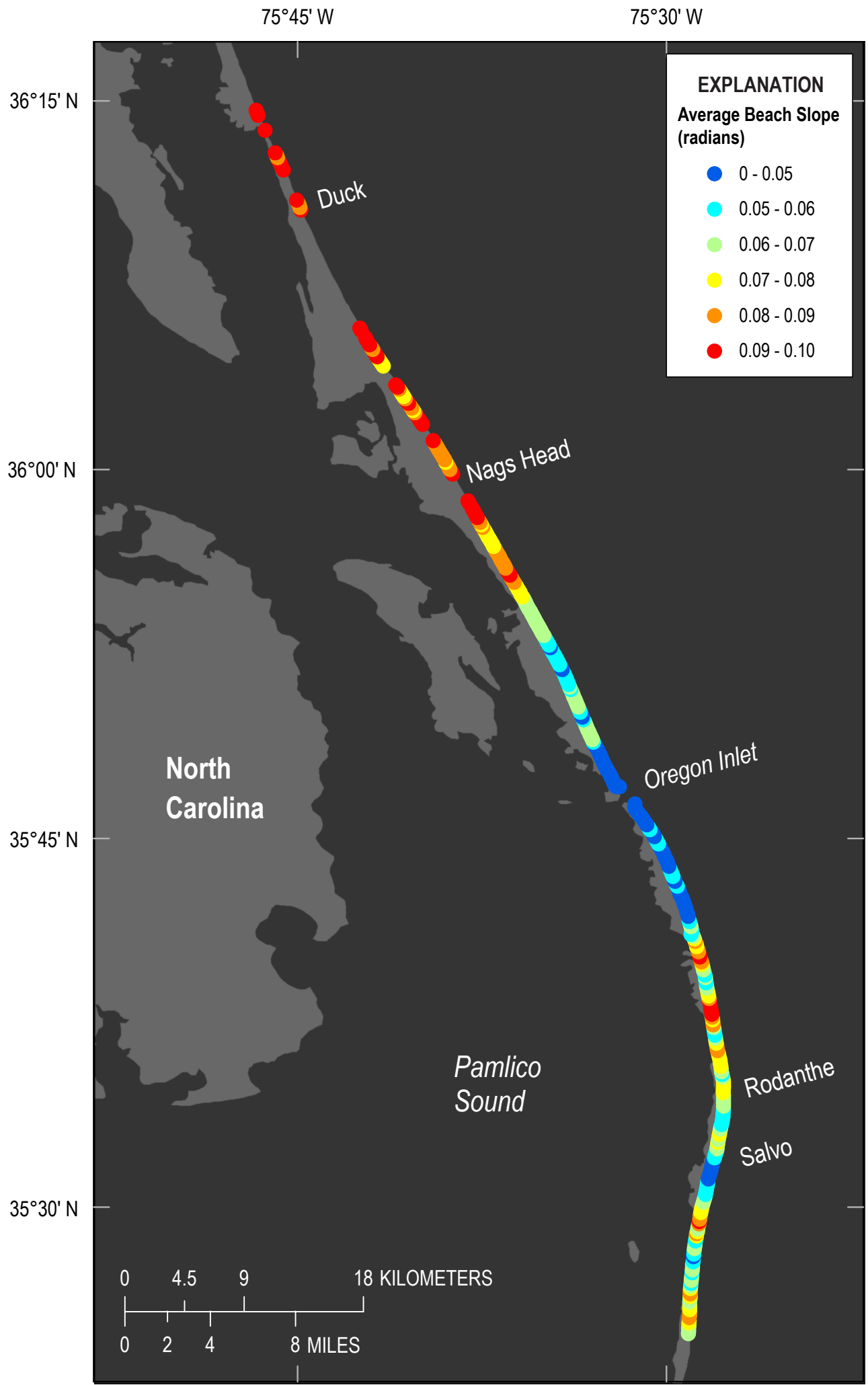

Esri, HERE, DeLorme, MapmyIndia, (๐ OpenStreetMap contributors, and the GIS user community

Figure 2. An example of spatially and temporally averaged beach slopes computed using data collected between 1996 and 2012 for the Outer Banks of North Carolina. 
error (MRE) of the raw slopes about the spatially and temporally averaged beach slope (see previous section). The mean residual error is defined as

$$
M R E=\sqrt{\frac{1}{N} \sum\left(\beta-\mu_{\beta}\right)^{2}}
$$

where $N$ is the number of raw beach slopes in each section, $\beta$ is a single raw beach slope, and $\mu_{\beta}$ is the spatially and temporally averaged beach slope. A 95 percent confidence interval is also provided, along with the MRE, and is defined as $2 \times$ MRE (fig. 3). If more than 50 percent of data are missing in the 400-m Hanning window, then the average beach slope and total uncertainty will not be computed. In general, the temporal variability in beach slope is an order of magnitude larger than the spatial uncertainty that exists within each 400-m Hanning window.

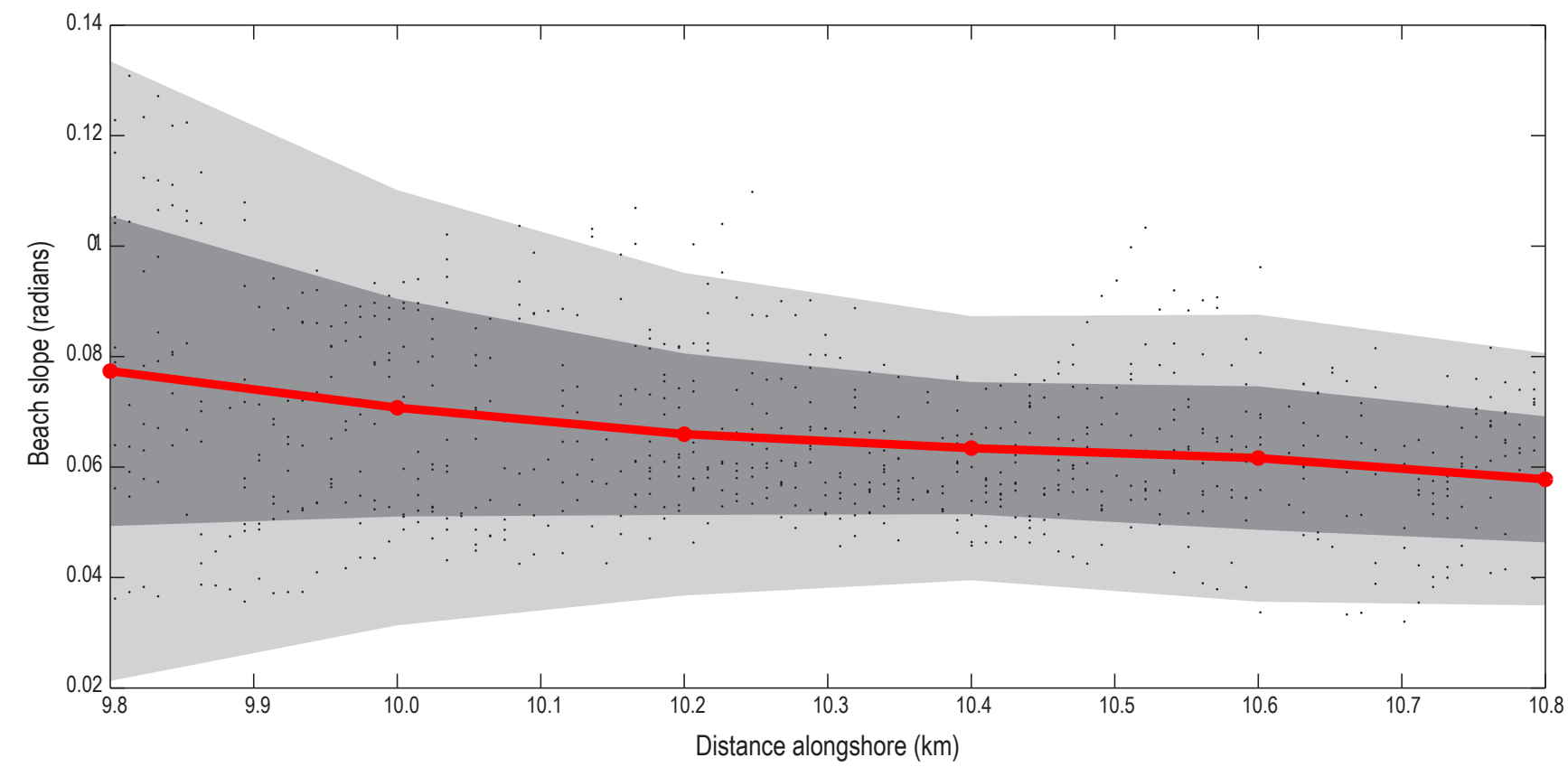

EXPLANATION

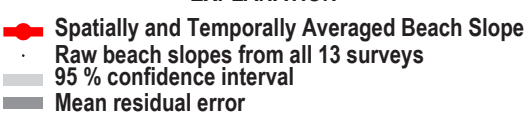

Figure 3. Spatially and temporally averaged beach slopes for a 1-kilometer (km) section of coast in the Outer Banks of North Carolina. Each average slope (red circle) represents the spatial and temporal average of the raw points (small black circles) within \pm 200 meters of the center point. The mean residual error (dark gray band) and 95 percent confidence interval (light gray band) are also shown. 


\section{References Cited}

Plant, N.G., Holland, K.T., and Puleo, J.A., 2002, Analysis of the scale of errors in nearshore bathymetric data: Marine Geology, v. 191, no. 1-2, p. 71-86.

Sallenger, A.H., Krabill, W., Swift, R., Brock, J., List, J., Hansen, M., Holman, R.A., Manizade, S., Sontag, J., Meredith, A., Morgan, K., and Stockdon, H., 2003, Evaluation of airborne scanning lidar for coastal change applications: Journal of Coastal Research, v. 19, p. 125-133.

Stockdon, H.F., Doran, K.J., Thompson, D.M., Sopkin, K.L., Plant, N.G., and Sallenger, A.H., 2012, National assessment of hurricane-induced coastal erosion hazards - Gulf of Mexico: U.S. Geological Survey Open-File Report 2012-1084, 51 p., accessed March 10, 2015, at http://pubs.usgs.gov/ of/2012/1084/.

Stockdon, H.F., Holman, R.A., Howd, P.A., and Sallenger, A.H., 2006, Empirical parameterization of setup, swash, and runup: Coastal Engineering, v. 53, no. 7, p. 573-588. 
